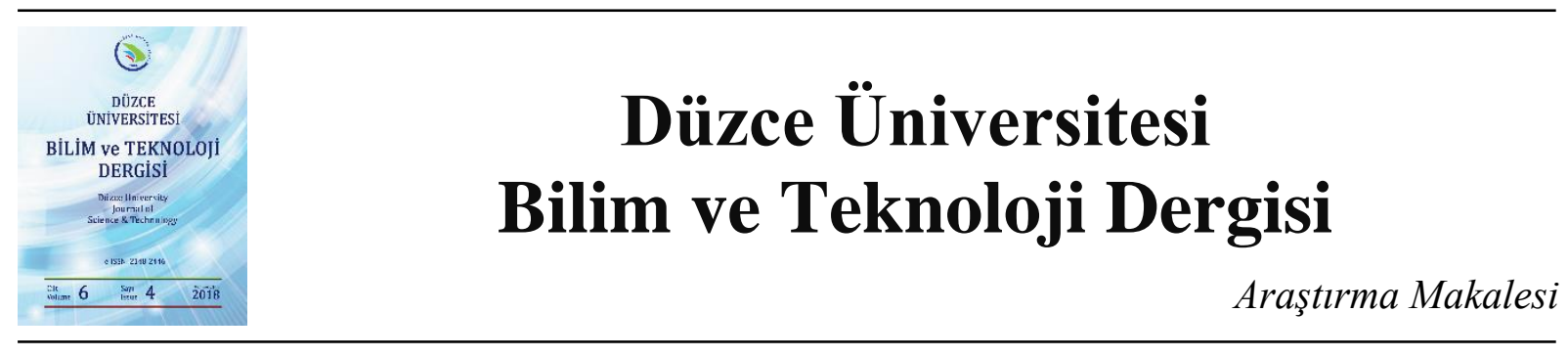

\title{
Düzce İli Fındık Depolarında Görülen Zararlı Böcekler ve Patojen Fungusların Tanımlanması
}

\author{
Salih KARABÖRKLÜ ${ }^{\mathrm{a},{ }^{*},}$ Nedim ALTIN ${ }^{\mathrm{a}}$ \\ ${ }^{a}$ Bitki Koruma Bölümü, Ziraat ve Doğa Bilimleri Fakültesi, Düzce Üniversitesi, Düzce, TÜRKIYY \\ *Sorumlu yazar: salihkaraborklu@duzce.edu.tr
}

\begin{abstract}
ÖZET
Zararlı böcekler ve hastalık etmenleri fındığın depolanması sırasında önemli ekonomik kayıplara neden olmaktadır. Bu çalışma findığın depolanması sırasında görülen zararlıların ve hastalık etmenlerinin belirlenmesi amacıyla yapılmıştır. Bu amaçla, Düzce il merkezi ve ilçelerinden 49 depodan findık örnekleri alınmış ve laboratuvarda incelenmiştir. İncelenen örneklerin \%51.02'sinde (25 örnekte) böceklerden kaynaklı zarar tespit edilmiştir. Bu örneklerde Curculio nucum, Plodia interpunctella ve Rhyzopertha dominica zararı tespit edilmiştir. Böcek yoğunluğu ise 0-6.67 (\%) arasında değişiklik göstermiş̧tir. İncelenen örneklerin \% 97.96'sında (48 örnekte) ise fungal hastalık etmenlerine rastlanmıştır. Fungal patojenlerden kaynaklı hastalık şiddeti (çürüklük oranı) ise 5.56-20.67 (\%) arasında değişiklik göstermiştir. İç çürüklüğe neden olan fungal etmenler, Aspergillus sp., Penicillium sp., Alternaria sp., Fusarium sp., Chaetomium sp., ve Trichothecium sp. olarak belirlenmiştir. Bu çalışma neticesinde findıkta zarar oluşturan ve çürüklüğe neden olan önemli zararlı ve fungal etmenler belirlenmiştir. Fındığın zararlı ve hastalıklardan korunması fındığın ekonomik değeri açısından oldukça önem taşımaktadır.
\end{abstract}

Anahtar Kelimeler: Depolama, Findık, Fungal patojenler, Hastalık şiddeti, Zararlı böcekler

\section{Determination of Insect Pests and Fungal Pathogens in Storages of Hazelnut in Duzce Province}

\begin{abstract}
Pest insects and fungal pathogens cause important economic loss in hazelnut during the storage period. In this study, we investigated these damaging agents in hazelnut storages. For this purpose, hazelnut samples were collected from 49 storages representing different location of Duzce and were checked in laboratory. Pest insect damage was determined in 25 storage samples (51.02\%). In these samples, hazelnut damage was detected caused by Curculio nucum, Plodia interpunctella and Rhyzopertha dominica. Pest insect intensity (\%) varied from 0 to 6.67 for Duzce province. Fungal pathogens were determined in the 48 storage samples (97.96\%). Prevalence rate (\%) of fungal pathogens varied among 5.56-20.67 in storages of Duzce. Isolating fungal agents from the inside of hazelnut were identified as Aspergillus sp., Penicillium sp., Alternaria sp., Fusarium sp., Chaetomium sp., and
\end{abstract}


Trichothecium sp. In this study, important pest insects and fungal pathogens were detected causing damage and rot in hazelnut. Protection of the hazelnut storages from these agents is very important for the economic value of hazelnut.

Keywords: Storage, Hazelnut, Fungal pathogens, Rate of rottenness, Pest insects

\section{GiRISS}

$\mathrm{F}$ 1ndık, Corylus avellane L. (Fagales: Betulaceae) Türkiye'nin en önemli sert kabuklu meyvelerinden birisidir [1]. Findık (C. avellane) özel yağ, protein, karbonhidrat, vitamin (E vitamini), mineral ve antioksidan fenolik içeriğinden dolayı oldukça besleyici özelliğe sahiptir [2]. Fındık bütün dünyada başta çikolata sanayi olmak üzere gıda sanayinde yoğun olarak kullanılmaktadır. Gıda sanayindeki kullanımının yanı sıra kozmetik ve ilaç sanayinde de kullanılmaktadır. Ayrıca findık oldukça yüksek yağ içeriğine de (tekli ve çoklu yağ asitlerinden oluşan) sahiptir [3].

Fındık üretiminin çok az ülkede ve kısıtlı alanlarda gerçekleştiriliyor olması bu ürünün üretimini ve ticaretini önemli bir duruma getirmiştir [1,4]. Yıllık ortalama üretim miktarı göz önüne alındığında (1 000000 ton), findık dünyada sert kabuklu meyveler içerisinde bademden sonraki en popüler ürün olarak dikkat çekmektedir [5,6]. Dünya findık üretimi 1960'lı yıllarda yıllık yaklaşık ortalama 250.000 ton civarında iken, günümüzde ise bu oran yıllık 797000 tona çıkmıştır [7]. Dünya findık üretiminin \%65-75'ini ve toplam ihracatın \%70-75'ini karşılayan Türkiye dünyanın en önemli findık üreticisi ve ihracatçısıdır [8]. Dünya findık ihracatında diğer önemli ülkeler ise İtalya, İspanya ve ABD olarak sıralanmaktadır [4]. Ülkemizde yaklaşık 400000 ailenin geçimini fındıktan sağladığı belirtilmektedir [9].

Fındık Ülkemizde başta Giresun, Ordu ve Trabzon olmak üzere Karadeniz'e kıyısı olan hemen hemen her ilde yetiştirilmektedir [4]. Düzce ili ve civarı nispeten yeni plantasyonlara sahip olması nedeniyle fındık üretimi açısından önemli bir konumda yer almaktadır. Düzce ili son beş yıllık ortalama veriler dikkate alındığında üretim alanı (626.850 dekar) bakımından Türkiye'de 6. sırada, üretim miktarı (54.493 ton) bakımından ise 4. sırada yer almaktadır. Dekara düşen ortalama verim ise $87 \mathrm{~kg}$ ' dır [10]. Ülkemiz, fındık üreten ülkeler içerisinde gerek üretim gerekse ihracat açısından ilk sırada yer almasına karşın birim alandan alınan ürün miktarları açısından diğer ülkelerin gerisinde bulunmaktadır [11].

Hasat sonrası findığın bir kısmı doğrudan satılmakla beraber büyük bir kısmı ise depolanmaktadır. Hasat sonrası depolama işlemi bazı kurum ve kuruluşlara ait büyük ölçekli depolarda, yerel orta ve küçük ölçekli depolarda ve üretici ev depolarında ihtiyaç ve duruma göre değişen süreler boyunca (124 aya kadar) depolanmaktadır [12].

Özellikle küçük ve orta ölçekli depolar ve üretici ev depolarının fındığın korunması açısından elverişsiz olduğu belirtilmektedir [13]. Depolanan findığın zararlılar ve hastalık etmenlerinden korunması oldukça önem taşımaktadır [14]. Depolama sırasında findıkta kalite ve ürün kaybına neden olan zararlı ve hastalık etmenleri bulunmaktadır. Zararlı ve hastalık etmenlerinden kaynaklanan randıman kaybı neticesinde fındığın ekonomik değeri de düşmektedir. 
$\mathrm{Bu}$ çalışma, Düzce ilinde hasat sonrası depolama sırasında findıkta görülen zararlı ve hastalık etmenlerinin belirlenmesi, bulaşıklık durumları, zararlı yoğunluğu ve hastalık şiddetinin belirlenmesi amacıyla yapılımıştır.

\section{MATERYAL VE YÖNTEM}

\section{A. FINDIK NUMUNELERININ ALINMASI}

Fındık üretim miktarları göz önüne alınarak incelenecek depo sayısı belirlenmiştir. Düzce il merkezi ve ilçelerinden toplam 49 depodan yaklaşık $500 \mathrm{~g}$ ' l1k findık örnekleri alınmıştır. Numuneler özel dikim bez torbalara alınarak laboratuvar ortamına getirilmiştir. Merkez ve ilçelerdeki incelenen depo sayıları Tabloda (Tablo 1) verilmiştir. Örnekler laboratuvarda oda sıcaklığında zararlı ve hastalık etmenlerinin tespitine kadar tutulmuştur.

\section{B. ZARARLI BÖCEKLERIN TESPITI}

Laboratuvara getirilen numunelerden rastgele seçilmek kaydıyla 30'ar adet findık alınmış ve findıklar kontrol edilmiştir. Fındık kurdu hasarı bulunan fındıklar belirlenmiş ve sayıları kaydedilmiştir. Daha sonra fındıklar kırılarak fındık içeriği kontrol edilmiştir. Fındık iç kısmında tespit edilen böcek yumurta, larva, pupa ve erginleri kaydedilmiştir. Böcek yumurta, larva ve pupaları tür teşhisinin netlik kazanması için içerisinde fındık kırıntıları bulunan plastik petrilere alınarak gelişimleri takip edilmiş ve ergin evreye ulaşmaları sağlanmıştır (Şekil 1). Ergin evreye ulaşan böcekler stereo mikroskop altında detaylı olarak incelenmiş ve tür tespitleri gerçekleştirilmiştir. Zararlı tespit edilen depolar bulaşık olarak not edilmiş ve bulaşıklık oranları belirlenmiştir.

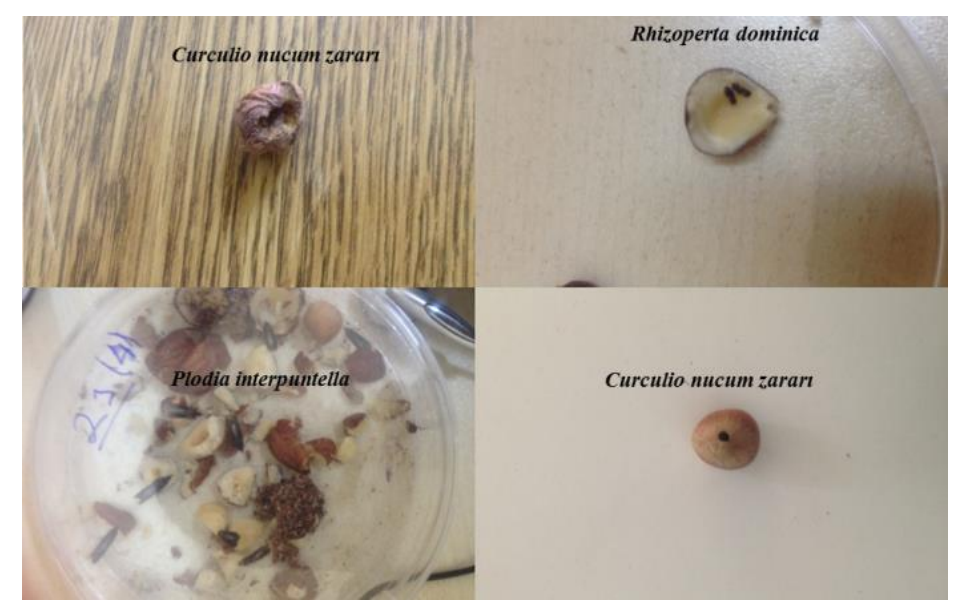

Şekil 1. Findıkta zarar meydana getiren böcekler

\section{HASTALIK ETMENLERININ BELIRLENMESI}

Laboratuvara getirilen findık numunelerinden rastgele 30 adet fındık alınarak kırılmıştır. Enfekteli görülen iç findıklar sayılmış ve hastalık şiddeti (\%) hesaplanmıştır. Hastalık tespit edilen depolar 
bulaşık olarak kaydedilmiş ve bulaşıklık oranları ayrıca hesaplanmıştır. Kontroller sonucunda çürük ve buruşuk olan iç findıklardan hastalık etmenlerinin belirlenmesi amacıyla ekim yapılmıştır (Şekil 2). Örnekler $\% 0.5$ 'lik sodyum hipoklorür içinde 1 dakika tutulmuş ve yüzey sterilizasyonu yapılmıştır. Sterilizasyondan sonra steril saf su ile durulanmış ve steril kurutma kağıdında kurutulmuştur. Daha sonra içinde $100 \mathrm{mg} \mathrm{L}^{-1}$ streptomisin sülfat bulunan PDA besi yeri içeren petrilere 4 parça halinde ekim yapılmıştır. Ekim sonrası petriler $24 \pm 1{ }^{\circ} \mathrm{C}$ sıcaklıkta inkubasyona bırakılmıştır. Gelişen fungus kolonilerinden tek spor ekim yöntemi ile funguslar saflaştırılmıştır. Elde edilen saf kültürler teşhisleri yapılıncaya kadar eğik agar tüplerine aktarılarak buzdolabında $+4^{\circ} \mathrm{C}$ 'de saklanmıştır.

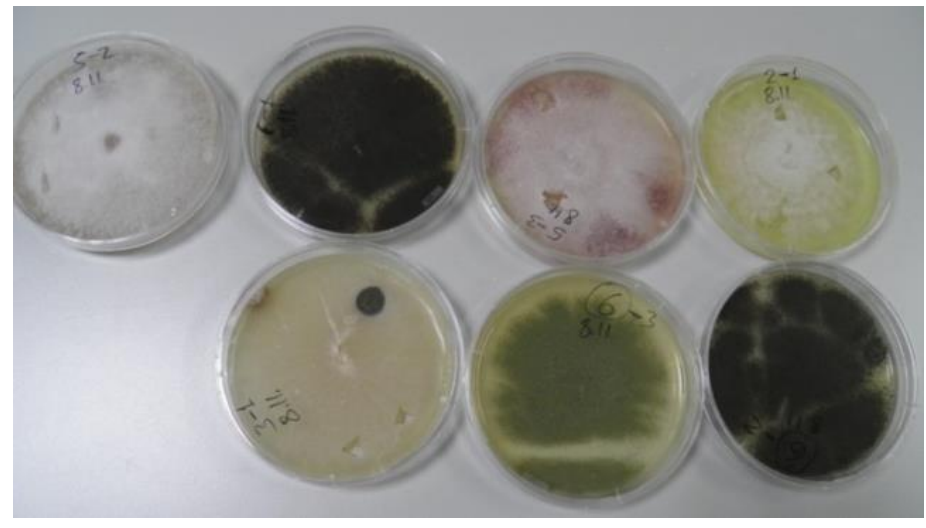

Şekil 2. Findıkta iç çürüklüğe neden olan etmenler

\section{ISTATISTIKSEL ANALIZ}

Zararlı böcekler ve fungal hastalık etmenlerinin yoğunluklarının karşılaştırılmasında SPSS (SPSS 17.0 commercial software, SPSS, Inc., Chicago, IL) programı kullanılarak varyans analizi (tek-faktör ANOVA) yapılmıştır. Normal dağılım için \% verilerin karekök dönüşümleri yapılmıştır. Ortalamalar \%5'lik güven aralığında Tukey-Kramer HSD post testi kullanılarak karşılaştırılmıştır.

\section{BULGULAR}

\section{A. ZARARLI BÖCEKLER ILE BULASIK DEPOLARIN BELIRLENMESI}

Fındıklar ilk önce fiziki olarak kontrol edilmiş, daha sonra ise kırılarak içeriği kontrol edilmiştir. Zararlı tespit edilen depolar kaydedilmiş ve zararlı bulaşıklık oranları belirlenmiştir (Tablo 1). İncelenen 49 depodan 25 tanesinde bulaşıklık tespit edilmiştir. İl genelindeki bulaşıklık oranı \%51.02 olarak belirlenmiştir. İlçeler (lokasyonlar) bazındaki bulaşıklık oranları ise (\%) 0 ila 80 arasında değişiklik göstermiştir. Gümüşova ilçesinden alınan örneklerde herhangi bir zararliya rastlanılmamıştır. En fazla bulaşıklık ise \% 80 ile Kaynaşlı ve Yığılca ilçelerinde görülmüştür (Tablo $1)$.

Tablo 1. Incelen depolar ve depoların zararlı böcekler açısından bulaşıklık durumları

\begin{tabular}{llll}
\hline Lokasyon & $\begin{array}{l}\text { İncelenen Depo } \\
\text { Sayısı }\end{array}$ & $\begin{array}{l}\text { Bulaşık Depo } \\
\text { Sayısı }\end{array}$ & $\begin{array}{l}\text { Bulaşıklık oranı } \\
(\%)\end{array}$ \\
\hline
\end{tabular}




\begin{tabular}{llll}
\hline Akçakoca & 13 & 6 & 46.15 \\
Cumayeri & 8 & 5 & 62.50 \\
Çilimli & 5 & 1 & 20.00 \\
Gölyaka & 3 & 1 & 33.33 \\
Gümüsşova & 3 & 0 & 00.00 \\
Merkez & 7 & 4 & 57.14 \\
Kaynaşlı & 5 & 4 & 80.00 \\
Yığılca & 5 & 4 & 80.00 \\
\hline İ geneli & $\mathbf{4 9}$ & $\mathbf{2 5}$ & $\mathbf{5 1 . 0 2}$ \\
\hline
\end{tabular}

\section{B. ZARARLI BÖCEKLERIN BELIRLENMESI}

Depolardan alınan örneklerde tespit edilen zararlı böceklerin teşhisleri yapılmış, yoğunluk durumları belirlenmiş ve lokasyonlar bazında dağılımları hesaplanmıştır (Tablo 2). İl genelinde zararlı yoğunluğu \%2.77 olarak kaydedilmiştir. Zararlı böceklerin en az görüldüğü lokasyon \% 0.67 ile Çilimli olmuştur. Zararlı yoğunluğunun en fazla olduğu bölge \%5.33 ile Kaynaşlı olurken, bu bölgeyi \%4.76 ve \%3.59 ile Merkez ve Akçakoca ilçeleri takip etmiştir. Zararlı yoğunlukları arasında lokasyonlar bazında farklılık olmasına karşın bu fark istatistiksel açıdan önemli bulunmamıştır $(F=$ 1.398; $d f: 7 ; P \leq 0.211)$. Zararlı dağılımları incelendiğinde depolardaki ürünlerde en fazla zarar yapmış olan türün fındık kurdu, Curculio nucum olduğu görülmüştür. Fındık kurdunu ise kuru meyve güvesi, Plodia interpuntella ve ekin kambur biti, Rhizoperta dominica takip etmiştir (Tablo 2). Fındık kurdu, Curculio nucum zararı Gümüşova dışında bütün lokasyonlarda görülmüş ve en fazla zararı Merkez (\%4.77) ve Kaynaşlı (\%4.67) bölgelerinde yapmıştır. Kuru meyve güvesi, Plodia interpuntella ise Akçakoca, Kaynaşlı ve Yığılca bölgelerindeki depolarda görülmüştür. Ekin kambur biti, Rhizoperta dominica ise yalnızca Cumayeri ilçesinde görülmüştür.

Tablo 2. Lokasyonlara göre zararlı yoğunluğu ve zararlı dă̆ılımı

\begin{tabular}{lllll}
\hline \multirow{2}{*}{ Lokasyon } & Yoğunluk (\%) & \multicolumn{2}{l}{ Zararlı Dă̆ılımı (\%) } \\
\cline { 3 - 5 } & $($ Ortalama \pm SH) & $\begin{array}{l}\text { Curculio } \\
\text { nucum }\end{array}$ & $\begin{array}{l}\text { Plodia } \\
\text { interpuntella }\end{array}$ & $\begin{array}{l}\text { Rhizoperta } \\
\text { dominica }\end{array}$ \\
\hline Akçakoca & $3.59 \pm 1.38 \mathrm{a}$ & 3.33 & 0.26 & - \\
Cumayeri & $3.33 \pm 1.09 \mathrm{a}$ & 2.92 & - & 0.42 \\
Çilimli & $0.67 \pm 0.67 \mathrm{a}$ & 0.67 & - & - \\
Gölyaka & $1.11 \pm 1.11 \mathrm{a}$ & 1.12 & - & - \\
Gümüşova & $0.00 \pm 0.00 \mathrm{a}$ & - & - & - \\
Merkez & $4.77 \pm 2.71 \mathrm{a}$ & 4.77 & - & - \\
Kaynaşlı & $5.33 \pm 2.26 \mathrm{a}$ & 4.67 & 0.67 & - \\
Yığılca & $3.33 \pm 1.05 \mathrm{a}$ & 2.67 & 0.67 & - \\
\hline İl geneli & $\mathbf{2 . 7 7 \pm 1 . 2 8}$ & $\mathbf{2 . 5 2}$ & $\mathbf{0 . 2 0}$ & $\mathbf{0 . 0 5}$ \\
\hline
\end{tabular}




\section{FUNGAL PATOJENLERLE BULAŞIK DEPOLARIN BELIRLENMESI}

Düzce ilinin farklı lokasyonlarından 49 findık deposundan alınan örneklerde fungal patojen varlığ da araştırılmıştır. Fındıklarda görülen fungal etmenlerin belirlenebilmesi için iç findıklar açılarak kontrol edilmiştir. Açılan iç fındıklar incelenerek enfeksiyon görülen findıklar kaydedilmiş, hastalık şiddeti ve bulaşıklık oranları (bulaşık depo sayısı) belirlenmiştir (Tablo 3). İl genelindeki depoların \%97.96'sının (49 depodan 48'inin) fungal patojenlerle bulaşık olduğu tespit edilmiştir. Akçakoca ilçesindeki bir depo haricinde örnekleme yapılan tüm findık depolarında bulaşıklık görülmüştür. Fındık depolarından alınan örneklerdeki çürüklük oranlarının (hastalık şiddeti) \%5.56 ile 20.67 arasında değiştiği görülmüştür.

Örnekleme yapılan lokasyonlar içerisinde en yüksek hastalık şiddeti \%20.67 ile Yığılca da görülmüsstür. Hastalık şiddeti bakımından Yığılca ile diğer lokasyonlar arasında istatistiksel olarak önemli bir fark olduğu görülmüştür $(F=2.399$; $d f: 8$; $P \leq 0.037)$. En düşük hastalık şiddeti ise $\% 5.56$ ile Gümüşova ilçesinde görülmüştür. İl genelindeki hastalık şiddeti ise \%13.13 olarak kaydedilmiştir.

Tablo 3. Lokasyonlara göre depolarının bulaşıklık oranları ve hastalık şiddetleri

\begin{tabular}{lllll}
\hline Lokasyon & $\begin{array}{l}\text { Kontrol Edilen } \\
\text { Depo Sayısı }\end{array}$ & $\begin{array}{l}\text { Bulaşık Depo } \\
\text { Sayısı }\end{array}$ & $\begin{array}{l}\text { Bulaşıklık } \\
\text { oranı }(\%)\end{array}$ & $\begin{array}{l}\text { Hastalık Şiddeti (\%) } \\
\text { (Ortalama } \pm \text { SH) }\end{array}$ \\
\hline Akçakoca & 13 & 12 & 92.31 & $14.87 \pm 2.35 \mathrm{ab}$ \\
Cumayeri & 8 & 8 & 100 & $06.25 \pm 1.33 \mathrm{a}$ \\
Çilimli & 5 & 5 & 100 & $09.33 \pm 2.45 \mathrm{ab}$ \\
Gölyaka & 3 & 3 & 100 & $15.56 \pm 4.01 \mathrm{ab}$ \\
Gümüşova & 3 & 3 & 100 & $05.56 \pm 2.22 \mathrm{a}$ \\
Merkez & 7 & 7 & 100 & $15.24 \pm 3.55 \mathrm{ab}$ \\
Kaynaşlı & 5 & 5 & 100 & $16.00 \pm 4.52 \mathrm{ab}$ \\
Yığılca & 5 & 5 & 100 & $20.67 \pm 3.56 \mathrm{~b}$ \\
\hline İl geneli & $\mathbf{4 9}$ & $\mathbf{4 8}$ & $\mathbf{9 7 . 9 6}$ & $\mathbf{1 3 . 1 3} \pm \mathbf{1 . 2 1}$ \\
\hline
\end{tabular}

\section{FUNGAL ETMENLERIN BELIRLENMESI}

Yapılan izolasyon çalışmaları sonucunda 6 fungus cinsine ait (Fusarium sp., Aspergillus sp., Trichothecium sp., Alternaria sp., Chaetomium sp. ve Penicillium sp.) toplam 105 fungal izolat elde edilmiştir (Tablo 4). İzolatlardan 26 tanesi Trichothecium cinsine aitken diğer cinslere ait izolat sayıları ise 7 ila 19 arasında değişiklik göstermiştir. Bunlardan Trichothecium cinsine ait izolatlar \%24.76 izolasyon oranı ile ilk sırada yer alırken bunu \%18.10 izolasyon oranı ile Fusarium ve Alternaria cinsleri izlemiştir. En düşük izolasyon oranı ise \%6.67 ile Chaetomium cinsinde görülmüştür. Fındıkta özellikle aflotoksin oluşumuna neden olan Aspergillus cinsine ait funguslar ise \%15.24 gibi bir oranda elde edilmiştir (Tablo 4). 
Tablo 4. İzolat sayılarl ve oranlarl

\begin{tabular}{lll}
\hline Fungal etmenler & Izolat sayısı & Izolasyon Oranı (\%) \\
\hline Fusarium $\mathrm{sp}$ & 19 & 18.10 \\
Aspergillus $\mathrm{sp}$ & 16 & 15.24 \\
Trichothecium $\mathrm{sp}$ & 26 & 24.76 \\
Alternaria $\mathrm{sp}$ & 19 & 18.10 \\
Chaetomium $\mathrm{sp}$ & 7 & 06.67 \\
Penicillium $\mathrm{sp}$ & 18 & 17.14 \\
\hline Toplam & $\mathbf{1 0 5}$ & $\mathbf{1 0 0}$ \\
\hline
\end{tabular}

\section{TARTIȘMA}

Uygun olmayan şartlarda findığın depolanması zararlıların ve hastalık etmenlerinin gelişimine ortam hazırlamaktadır. Fındığın depolanması sırasında görülen zararlılar ve hastalık etmenleri findık kalitesini olumsuz yönde etkilemekte ve findıkta ciddi ekonomik kayıplara neden olmaktadır $[15,16]$.

Yaptığımız araştırma neticesinde Düzce ilindeki findık depolarının \%51.02'sinde zararlı böceklere rastlanmıştır. Zararlı böceklerle bulaşıklık oranlarının ilçeler bazında (\%) 0 ila 80 arasında değişiklik gösterdiği belirlenmiştir. Samsunda yapılan bir çalışmada ise 11 findık işleme tesisinden kabuklu fındık, iç findık ve bunlara ait kırıntılardan örnekler alınmış ve zararlı böcek bulaşıklığı incelenmiştir. Fındık işleme tesislerinin tamamının zararlı böceklerle bulaşık olduğu belirlenmiştir [15]. Düzce ilindeki depolarda bulunan zararlı böceklerin yoğunlukları da incelenmiş ve zararlı yoğunluğu ilçeler bazında \%0 ila \%6.67 oranında değişiklik göstermiştir. Fındık danelerinde zarar oluşturan zararlıların dağılımı incelendiğinde ise fındık kurdu, Curculio nисит L. (Col., Curculionidae) hasarlı findıkların yoğunlukta olduğu görülmüştür. Fındık kurdunu ise kuru meyve güvesi, Plodia interpunctella (Hübner) (Lep., Pyralidae) ve ekin kambur biti, Rhyzopertha dominica (F.) (Col., Bostrichidae) takip etmiştir. Samsunda yapılan çalışmada ise işleme tesislerinde en yoğun bulunan böceğin kırma biti, Tribolium confusum Jacquelin du Val (Col.: Tenebrionidae) olduğu rapor edilmiştir. Bu zararlıy sirasiyla kuru meyve güvesi, P. interpunctella, incir kurdu, Ephestia cautella (Walker) (Lep., Pyralidae), un biti, Tribolium castaneum (Herbst) (Col.,: Tenebrionidae) ve dişli böcek, Oryzaephilus mercator (Fauvel) (Col., Silvanidae) takip etmiştir [15]. Diğer bir raporda ise Ordu ve Giresun'da bulunan findık işleme tesislerinde $P$. interpunctella, $P$. farinalis, $P$. gularis ve E. cautella varlığ belirtilmiştir [17].

Düzce'de İncir kurdu, kırma biti, un biti ve dişli böceğe rastlanılmamıştır. Samsunda yapılan çalışmadan farklı olarak ise ekin kambur biti tespit edilmiştir. Yaptığımız çalışmada yalnızca depolardan örnek alınmış ve kırılmamış findıklar kullanılmıştır. Samsun'da yapılan çalışma ise findık işleme tesislerinde gerçekleştirilmiş kırılmamış fındıkların yanı sıra iç fındık ve döküntü materyalleri de kullanılmıştır. Döküntü materyallerine depo zararlılarının ulaşmasının daha kolay olması nedeniyle tespit edilen tür sayısında da artış görülmüştür. Fındık kurdu, C. nucum findık depo zararlısı olmamasına karşın bu zararının neden olduğu delikli veya zarar görmüş findıkların depoya geçmesi ve önemli randıman kaybına neden olması nedeniyle, çalışmada bu zararlıya da yer verilmiştir. Fındık üretim alanlarındaki en önemli zararlının fındık kurdu (Curculio nucum) olduğu birçok araştırıcı tarafından rapor edilmiştir [18-20]. Fındık kurdu erginleri karanfiller ile beslenerek karanfillerin kuruyup dökülmesine ve ayrıca meyveyle beslenerek fındıklarda sarıkaramuk, karakaramuk ve delikli meyvelerin oluşmasına neden olmaktadır [21]. Yaptığımız çalışmada da oldukça yoğun bir şekilde 
findık kurdu hasarlı findıklara rastlanılmıştır. Kuru meyve güvesi kozmopolitan bir zararlı olup depolanmış tahıllarda, fistık, bakliyat, kuru meyve ve işlenmiş gıdalara bulaşarak ürün kalitesini bozmakta ve önemli ürün kayıplarına neden olmaktadır [22,23]. Kendi çalışmamız ve diğer çalışmalardan elde edilen sonuçlar bu zararlının fındık depolarında ve fındık işleme tesislerinde zarar oluşturduğunu kanıtlamaktadır [17]. Ekin kambur biti ise depolanmış tahıllarda ve diğer ürünlerde zarar oluşturan kozmopolitan zararlılardan bir diğeridir [24]. Zararlı ülkemizde tahıl depolarında yaygın olarak bulunmakta ve özellikle buğday, mısır, arpa, çavdar taneleri ve makarnalarda zarar oluşturmaktadır [25]. Bildiğimiz kadarıyla findık depolarında ekin kambur biti zararına dair bir bilgi bulunmamaktadır. Bu zararlının fındık depolarında da bulunabileceği ilk kez yapılan bu çalışma ile ortaya konmuştur.

Fındık depolarında bulunan hastalık etmenleri incelendiğinde ise depoların nerdeyse tamamının (\%97.98) hastalık etmenleriyle bulaş1k olduğu belirlenmiştir. Fungal etmenlerden kaynaklı hastalık şiddeti (iç çürüklük oranı) \%5.56 ile \%20.67 arasında değişiklik göstermiştir. ABD’de yapılan bir çalışmada bazı bahçelerde iç çürüklüğü nedeniyle oluşan kayıpların \%3-10 arasında değiştiği belirtilmiştir [26]. Bremer [27] çürümekte olan findıklar üzerinde Trichothecium roseum, Dothiorella sp. ve Cryptostictis sp. etmenlerinin tespit edildiğini bildirmiştir. Çürüklüklerde rutubetin önemli rol oynadığı belirtilmiştir. Çalışmamızda elde edilen hastalık şiddetinin (\%5.56-20.67) daha önce yapılan çalışmalardan elde edilen hastalık şiddetlerinden daha yüksek olduğu görülmektedir. Düzce ilinde nemin yüksek olması ve hasat sonrası dönemde bölgede genellikle yağışlı ve serin bir iklimin sürmesi nedeniyle bahçeden bulaşık olarak gelen findıklardaki çürüklük oranları depo şartlarında daha da yükselmektedir.

Yaptığımız çalışma sonucu, depolardaki findıklarda sorun olan etmenler; Fusarium sp, Aspergillus sp, Trichothecium sp, Alternaria sp, Chaetomium sp ve Penicillium sp. olarak tespit edilmiştir. Ülkemizde yapılan bir çalışmada başta Aspergillus spp. ve Penicillium sp. olmak üzere Cladosporium spp., Cephalosporium spp., Alternaria spp., Rhizopus spp., Mucor spp., Trichothecium roseum, Fusarium spp., Pestalozzia spp., Verticillium spp., Oospora spp., Macrosporium sp., Botryodiplodia sp., Glomerella sp., tespit edilmiştir [16]. Bazı saprofitik fungusların sert kabuklu meyvelerde iç çürüklüklerine neden olduğu ve bunların Alternaria, Aspergillus, Cladosporium, Eurotium, Fusarium, Penicillium, Rhizopus, Trichothecium ve Ulocladium cinslerini içeren funguslar olduğu rapor edilmiştir [26].

Çoğunlukla saprofitik veya zayıf parazitik olan Trichothecium cinsi dünya genelinde yaygın olarak bulunabilmektedir [28]. Bu cins Corylus'larda yere düşen dallarda tespit edilmiştir [16]. Çalışmamızda da Trichothecium sp. en yüksek (\%24.76) izolasyon oranına sahip fungal etmen olmuştur. Fındıklarda iç çürüklüğü ancak kabuk kırıldıktan sonra tespit edilebilmektedir. İspanyada yapılan bir çalışmada kabukları kırıldıktan sonra çürüklük belirtisi gösteren findıklarda Alternaria sp. izole edilmiştir [29]. Çalışmamızda da kabuklar kırıldıktan sonra yapılan izolasyonlar sonucunda elde edilen izolatlardan \%18.10'nu Alternaria sp. izolatlarının oluşturduğu görülmüştür. Çalışmamızda Aspergillus sp. de izole edilmiştir. Bilindiği gibi bazı Aspergillus türleri insan sağlığını olumsuz etkileyen aflotoksin üretmektedirler. Findıkta bulunan A. flavus ve A. parasiticus fungusları aflotoksin üretmeleri yönüyle önemlidir [30]. Çalışmamızda \%15.24 gibi bir izolasyon oranına sahip olan Aspergillus sp. dikkat çekmektedir. 


\section{SONUC}

Sonuç olarak, uygun olmayan şartlarda findığın depolanması zararlıların ve hastalık etmenlerinin gelişimine ortam hazırlamaktadır. Bu durum fındık kalitesini olumsuz yönde etkilemekte ve fındıkta ciddi ekonomik kayıpların yaşanmasına neden olmaktadır. Yapılan bu çalışma, uygun olmayan hasat, kurutma ve depolama yöntem ve koşulları neticesinde findık depolarında önemli oranlarda zararlı ve hastalık etmenin geliştiğini ortaya koymuştur. Daha uygun hasat, kurutma ve depolama yöntemlerinin geliştirilmesi ve daha uygun depoların seçimi findığın zararlı ve hastalık etmenlerinden korunmasını sağlayacaktır.

TEŞEKKÜR: $\mathrm{Bu}$ çalışma Düzce Üniversitesi Bilimsel Araştırma Projeleri Koordinatörlüğü tarafından desteklenmiştir (Proje no: 2012.05.01.001).

\section{KAYNAKLAR}

[1] F. Akyazı, S. Y1ld1z and A.F. Felek, "Soil nematode communities associated with hazelnut orchards in Turkey," Journal of Entomology and Nematology, vol. 6, no. 8, pp. 112-121, 2014.

[2] C. Alasalvar, F. Shahidi, C.M. Liyanapathirana and T. Ohshima, "Turkish Tombul hazelnut (Corylus avellana L.). 1. Compositional characteristics," Journal of Agricultural and Food Chemistry, vol. 51, no. 13, pp. 3790-3796, 2003.

[3] T. Delgado, R. Malheiro, J.A. Pereira and E. Ramalhosa, "Hazelnut (Corylus avellana L.) kernels as a source of antioxidants and their potential in relation to other nuts," Industrial Crops and Products, vol. 32, no. 3, pp. 621-626, 2010.

[4] O.İ. Güney, "Turkish hazelnut production and export competition," YYÜ Tartm Bilimleri Dergisi (YYU J AGR SCI)," vol. 24 no. 1, pp. 23-29, 2014.

[5] M. Contini, S. Baccelloni, R. Massantini and G. Anelli, "Extraction of natural antioxidants from hazelnut (Corylus avellana L.) shell and skin wastes by long maceration at room temperature," Food Chemistry, vol. 110, no. 3, pp. 659-669, 2008.

[6] H. Ciemniewska-Zytkiewicz, V. Verardo, F. Pasini, J. Brys, P. Koczon and M.F. Caboni, "Determination of lipid and phenolic fraction in two hazelnut (Corylus avellana L.) cultivars grown in Poland," Food Chemistry, vol. 168, no. 1, pp. 615-622, 2015.

[7] A.R. Aktaş, E. Öztürk ve S.A. Hatırl1,. "Dünya findık piyasasında Türkiye'nin rolü,” SDÜ Vizyoner Dergisi, c. 1, s. 1, ss. 36-54, 2009.

[8] İ. Saruhan ve C. Tuncer, "Fındık kokarcas1 (Palomena prasina L. Heteroptera: Petatomidae)'nın findık meyvelerindeki zarar şekli ve oranı," Anadolu Tarım Bilimleri Dergisi, c. 25, s. 2, ss. 75-83, 2010. 
[9] M. Bozoğlu, "Econometric analysis of hazelnut productivity in Ordu and Giresun provinces, Turkey," Proc. V. Int. Congress on Hazelnut, Ed. S.A. Mehlenbacher, Acta Horticulturae (ISHS), vol. 556, pp. 125-129, 2001.

[10] TÜİK, 2016. Türkiye İstatistik Kurumu (2017, 25 Aralık). Bitkisel üretim istatistikleri. Erişim: http://www.tuik.gov.tr/PreTablo.do?alt_id=1001.

[11] O. K1lıç, "Fındıkta dönüm noktası," Tarım ve Köyişleri Bakanlı̆̆ı Dergisi, Tarım ve Köy, c. 97, ss. 38-40, 1994.

[12] T. Öztürk ve A. Uzun, "Fındık depolamasında kullanılan bunker silolarda projeleme yükleri ve yapısal başarısızlıklar," Akademik Ziraat Dergisi, c. 3, s. 1, ss. 45-52, 2014.

[13] H. Anaç, "Tarım Sektörü Raporu, Sektörel Raporlar Serisi I”, Doğu Marmara Kalkınma Ajans1, İzmit, Türkiye, 2011.

[14] Anonim, "Fındıkta Verim ve Kaliteyi Arttırma Projesi". Tabzon Ticaret Borsası, Trabzon, Türkiye, 2014.

[15] S.K. Ozman-Sullivan, H. Ocal and N. Celik, "Insect pests of stored hezalnuts in Samsun Province, Turkey,". Proc. VII ${ }^{\text {th }}$ Intern. Congress on Hazelnut, Acta Horticulturae (ISHS), vol. 845, pp. 515-520, 2009.

[16] A. Sezer, "Ordu Giresun ve Trabzon illerinde findıkta meyve ve çotanak hastalıklarına neden olan fungal etmenlerin ve çeşit reaksiyonlarının belirlenmesi," Doktora tezi, Fen Bilimleri Enstitüsü, Ankara Üniversitesi, Ankara, Türkiye, 2012.

[17] E. Yasan ve G. Kiper, "Doğu Karadeniz Bölgesi findık depolarında ekonomik zararlara neden olan Cadra cautella Walk. ve Plodia interpunctella Hb.' nın biyolojileri, zarar nisbetleri ve mücadeleleri üzerinde araştırmalar," Zirai Mücadele Araştırma Yıllı̆̆g, ss. 71-73, 1972.

[18] O. Ecevit, C. Tuncer ve G. Hatat, "Karadeniz Bölgesi bitki sağllğı problemleri ve çözüm yollar1," OMÜ Ziraat Fakültesi Dergisi, c. 10, s. 3, ss. 191-206, 1995.

[19] S. Milenkovic and M. Mitrovic, "Hazelnut pests in Serbia". Proc. V. Int. Congress on Hazelnut, Acta Horticulturae (ISHS, ) vol. 556, pp. 403-409, 2001.

[20] İ. Akça ve C. Tuncer, "Biological control and morphological studies on nut weevil (Curculio nucum L. Col., Curculionidae),” Acta Horticulturae (ISHS), vol. 686, pp. 413-420, 2005.

[21] İ. Saruhan ve M. Şen, "Farklı findık çeşitlerinde findık kurdunun (Curculio nucum Col.: Curculionidae) zarar oran1," Anadolu Tartm Bilimleri Dergisi, c. 27, s. 2, ss. 70-75, 2012.

[22] A. Ayvaz, S. Albayrak and S. Karaborklu, "Gamma radiation sensitivity of the eggs, larvae and pupae of Indian meal moth Plodia interpunctella (Hübner) (Lepidoptera: Pyralidae)," Pest Management Science, vol. 64, no. 5, pp. 505-512, 2008. 
[23] A. Ayvaz, O. Sagdic, S. Karaborklu and I. Ozturk, "Insecticidal activity of the essential oils from different plants against three stored product insects," Journal of Insect Science, vol. 10:21 available online: insect science. org/10.21, 2010.

[24] D.W. Hagstrum and B. Subramanyam, Stored Product Insect Source. St Paul, AACC International, Minnesota, USA, 2009, p. 509.

[25] N. Şayeste, "Rhyzopertha dominica F.'nın çeşitli ökolojik şartlarda biyolojisi ile bu türe değişik sıcaklık ve nemde Alüminyum Phosphide'in etkileri üzerinde araştırmalar," Ankara, Türkiye: Tisa Matbaacıl1k Sanayii, 1971, s. 75.

[26] M.A. Doster, K.B. Johnson, T.J. Michailides, J.K. Stone and B.L. Teviotdale, "Kernel Decay". in Compendium of Nut Crop Diseases in Temperate Zones, St. Paul, MN, USA: Amer Phytopathological Society Press, 2002. pp. 2-3.

[27] H. Bremer, Türkiye Fitopatolojisi, Ankara, Türkiye: Güney Matbaacıl1k ve Gazetecilik TAO, 1948, Cilt II, Özel Bölüm, Kısım 1, s. 237.

[28] S. Samsi and R Sultana, "Trichothecium roseum Link - A new record of Hyphomycetous fungus for Bangladesh," Bangladesh Journal of Plant Taxonomy, vol. 15, no. 1, pp.77-80, 2008.

[29] A. Torrell, G. Barrios and M. Escofet, "The evolution of hazelnut phytosanitary problems in tarragona," Acta Horticulturae (ISHS), vol. 686, pp. 619-623, 2005.

[30] L. Snare, Pest and Disease Analyses in Hazelnut. Horticultural Australia Ltd. Project No: NTO5OO2, 2006, p. 64. 